\title{
Using Satellite Image Fusion to Evaluate the Impact of Land Use Changes on Ecosystem Services and Their Economic Values
}

\author{
Wang Shuangao ${ }^{1, *}$, Rajchandar Padmanaban ${ }^{2}$ (D) Aires A. Mbanze 2,3,4 , João M. N. Silva ${ }^{2}$ (D), \\ Mohamed Shamsudeen ${ }^{5,6}$, Pedro Cabral ${ }^{7}$ (D) and Felipe S. Campos ${ }^{7}$ (iD \\ 1 Shoujian Financial Center, Beijing Institute of Science and Technology Information, No. 140, \\ Xizhimenwai Street, Xicheng District, Beijing 100044, China \\ 2 Forest Research Centre, School of Agriculture, University of Lisbon, 1349-017 Lisboa, Portugal; \\ rajchandar@isa.ulisboa.pt (R.P.); ambanze@unilurio.ac.mz (A.A.M.); joaosilva@isa.ulisboa.pt (J.M.N.S.) \\ 3 Nova School of Business and Economics, Universidade Nova de Lisboa, 2775-405 Carcavelos, Portugal \\ 4 Faculty of Agrarian Sciences, Department of Environment and Nature Conservation, Universidade Lúrio, \\ Sanga 3302, Mozambique \\ 5 Thoothukudi Campus, College of Engineering, Anna University, University V.O.C., Tamil Nadu 628008, India; \\ shamsudeen@asprotechnologies.com \\ 6 Aspro Technologies, 33, 3rd Floor, Srirose Complex, Muthamil Street, Veepamoodu Junction, \\ Nagercoil 629001, India \\ 7 NOVA Information Management School (NOVA IMS), Campus de Campolide, Universidade Nova de Lisboa, \\ 1070-312 Lisbon, Portugal; pcabral@novaims.unl.pt (P.C.); fcampos@novaims.unl.pt (F.S.C.) \\ * Correspondence: h130031@e.ntu.edu.sg
}

\section{check for} updates

Citation: Shuangao, W.; Padmanaban, R.; Mbanze, A.A. Silva, J.M.N.; Shamsudeen, M.; Cabral, P.; Campos, F.S. Using Satellite Image Fusion to Evaluate the Impact of Land Use Changes on Ecosystem Services and Their Economic Values. Remote Sens. 2021, 13, 851. https://doi.org/10.3390/ rs13050851

Academic Editor: Dimitrios Alexakis

Received: 19 January 2021

Accepted: 22 February 2021

Published: 25 February 2021

Publisher's Note: MDPI stays neutral with regard to jurisdictional claims in published maps and institutional affiliations.

Copyright: (c) 2021 by the authors. Licensee MDPI, Basel, Switzerland. This article is an open access article distributed under the terms and conditions of the Creative Commons Attribution (CC BY) license (https:// creativecommons.org/licenses/by/ $4.0 /)$.
Abstract: Accelerated land use change is a current challenge for environmental management worldwide. Given the urgent need to incorporate economic and ecological goals in landscape planning, cost-effective conservation strategies are required. In this study, we validated the benefit of fusing imagery from multiple sensors to assess the impact of landscape changes on ecosystem services (ES) and their economic values in the Long County, Shaanxi Province, China. We applied several landscape metrics to assess the local spatial configuration over 15 years (2004-2019) from fused imageries. Using Landsat-7 Enhanced Thematic Mapper Plus (ETM+), Landsat-8 Operational Land Imager (OLI) and Indian Remote Sensing Satellite System Linear Imaging Self Scanning Sensor 3 (IRS LISS 3) imageries fused for 2004, 2009, 2014 and 2019, we reclassified land use/land cover (LULC) changes, through the rotation forest (RF) machine-learning algorithm. We proposed an equivalent monetary metric for estimating the ES values, which also could be used in the whole China. Results showed that agriculture farmland and unused land decreased their spatial distribution over time, with an observed increase on woodland, grassland, water bodies and built-up area. Our findings suggested that the patterns of landscape uniformity and connectivity improved, while the distribution of landscape types stabilized, while the landscape diversity had a slight improvement. The overall ES values increased (4.34\%) under a benefit transfer approach, mainly concerning woodland and grassland. A sensitivity analysis showed the selected economic value (EV) was relevant and suitable for the study area associated with our ES for LULC changes. We suggested that changes in landscape patterns affected the ESV trends, while the increases on some LULC classes slightly improved the landscape diversity. Using an interdisciplinary approach, we recommend that local authorities and environmental practitioners should balance the economic benefits and ecological gains in different landscapes to achieve a sustainable development from local to regional scales.

Keywords: landscape patterns; urban ecosystem services; environmental monitoring; remote sensing; image fusion

\section{Introduction}

Anthropic pressure on human-induced landscapes is the main driver of land use/land cover (LULC) changes and its effects on ecosystem services (ES) $[1,2]$ which is key to 
mitigate negative impacts for improved conservation outcomes. The use of ES has been proposed to define important contributions of ecosystems to human well-being, representing a link between biodiversity conservation and development needs [3]. However, ecological disturbances can affect several landscape patterns and their role in the provisioning of indispensable goods and services, such as potable water, non-timber forest products (NTFPs), erosion protection and soil nutrition [4-6]. The relation between landscape change and ES is mutually dependent. For instance, land use changes can lead to strong or slight alterations in ecosystem components, structures, ecological processes and biodiversity patterns [3,7]. On the other hand, the degradation and losses on the ES also affect the structure and aesthetic of landscape, with serious consequences for human safety and health, and directly threaten regional and even global ecological integrity [8]. Therefore, studying the changes of landscape patterns on ES can effectively grasp the changing trend of regional ecological environment, rationally allocating land use activities to promote harmonious and sustainable development goals for human and nature $[9,10]$.

The inclusion of economic costs in ES assessments is an important premise of ecological valuation to support environmental compensation policies [9], which could improve global and national green development accounts [11]. Globally, quantitative analyses of ES valuation suggest a need for the development of land use plans that optimally balance economic costs and ecological constraints in fast-developing countries [12-14]. China is one of the fast-growth emerging nations in the world [2], achieving its higher record of gross domestic product (GDP) development of $9.6 \%$ in the last 20 years $[15,16]$. However, this relative fast growth was made at the expense of the ES depletion and high environmental damage [17-19]. With increasing negative environmental externality that affected the wellbeing and the public health of their local citizens [15], the Chinese government decided to embrace an ambitious plane of sustainable development that required changes in key sectors such as agriculture, energy and industry $[6,15,16,20,21]$. As a result, there have been a growing number of studies attempting to measure landscape enhancement and the value of the different ES [8-10,14,22]. Yet, only a few studies address the impact of those programs on landscape recovering $[23,24]$, and the ecological values arise from the enhancement of ES [4]. The correctness of this assessment technique is still low and does not conform to China's national conditions [25]. Regarding the research results of foreign countries, made some necessary improvements to analyze the dynamic changes of China's regional ES and estimate its economic value. However, this method was never being ascertained in small-scale areas out of the Chinese countrywide.

Remote sensing (RS) provides many approaches to evaluate LULC changes in urban and rural landscapes, as well as for estimating the socio-economic impacts of ES [26]. Available RS approaches determine the benefits for LULC monitoring and calculating economic values on ES over conventional techniques that are based on field investigation combined with single sensor satellite images or aerial photographs [15]. Therefore, RS practices have been extensively applied for estimating LULC changes associated with economic impacts on ES in several countries worldwide, such as Germany, USA, Canada, and India [13,14,27]. Predominantly, the advantage of combining/fusing data from multiple sensors with varied spectral and spatial resolution provides more detailed information than the single sensor analysis [26]. Fused imagery from multiple sensors deliver significant metrics for the estimation of LULC change dynamics in an urban area as well as the quantification of the relationship between variations in ES and their economic values $[27,28]$.

In this research, we evaluate land use changes on ES and their EV in Long County, China, from 15 years (2004-2019) using RS images. We select this area because it is an agricultural county in a poor mountainous area of the Shaanxi Province with a fragile ecological environment [29-31], where the growth of human population and urbanization has been exacerbating the existing scarce natural resources [29]. We aim to explore how land use changes can influence environmental policies implementation for regional sustainable development, focused on ES enhancement and protection, landscape dynamics and resource allocation in the region. To achieve this aim, we develop an integrative spatial 
approach with the following specific objectives: (i) to compute 15 years of LULC change dynamics in the Long County using fused imageries; (ii) to quantify the landscape patterns and characteristics of its structure and spatial configuration using landscape metrics; (iii) to assess ES value based on the ecological value estimation method; and (iv) to verify if the selected economic value is relevant and suitable for the study area using the sensitivity analysis. This paper is organized as follows. Sections 2.1 and 2.2 describes the study area and data used in this work. Section 2.3 summarize the research design of this paper. Section 2.4 provides information about satellite data preprocessing followed. Section 2.5 describes the image fusion method. Section 2.6 provides step by step rotation forest classification algorithm to produce LULC maps. Section 2.7 explains different method followed in this project for landscape pattern evaluation. Section 2.8 explains the method used in this work to assess ecosystem services value. Section 2.9 explains the sensitivity analysis. Section 3 then combines the results from the individual stages of the research design to evaluate land use and land cover changes on ecosystem services and their economic values. Finally, Sections 4 and 5 provide the discussion and conclusions.

\section{Materials and Methods}

\subsection{Study Area}

The study is focused on Long County, located in the west of Guanzhong Plain and the northwest of Baoji City, China (Figure 1). Long County is $57.6 \mathrm{~km}$ wide from north to south, $59.7 \mathrm{~km}$ long from east to west [32]. The climate of the region is sub-humid continental monsoon with an average temperature of $10.9^{\circ} \mathrm{C}$, a frost-free period is 197 days [31]. The average yearly precipitation is $677.1 \mathrm{~mm}$ [31].

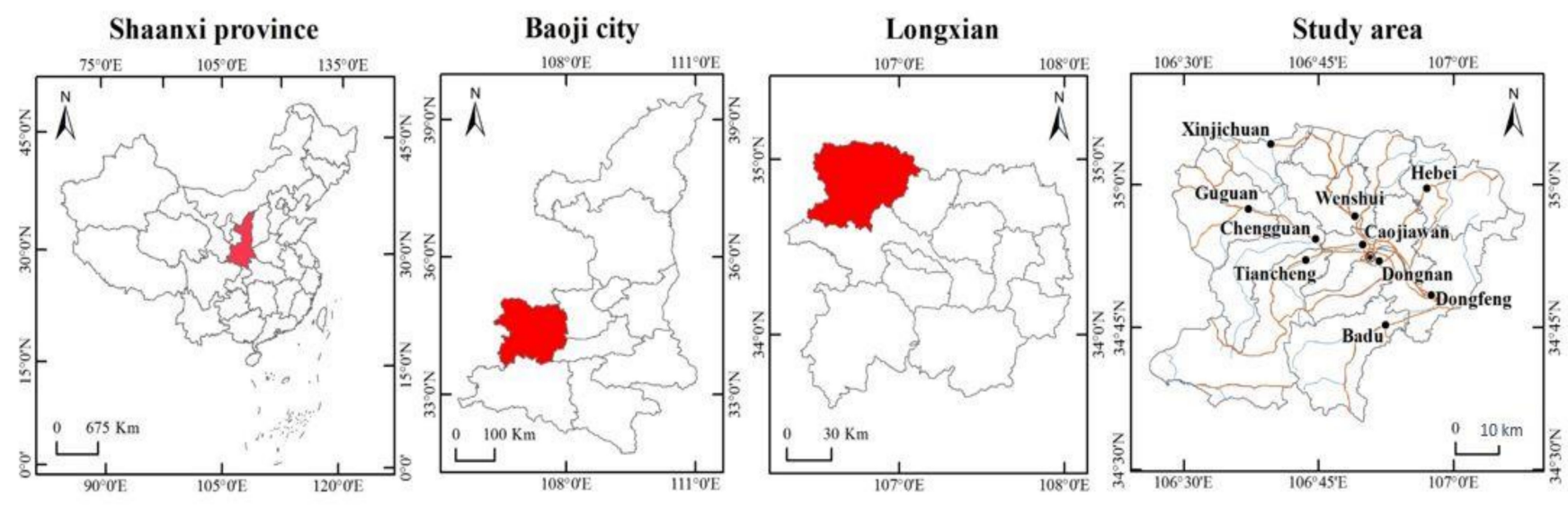

Figure 1. Study area covering the Longxian (Long) County, Baoji City, Shaanxi Province, China.

In 2019, Longxian (Long) County governs 10 towns, with a population of 252,000, realizing a regional GDP of 9.155 billion yuan, including 1.863 billion yuan of the added value of the primary industry, 3.763 billion yuan of added value of the secondary industry, and 3.529 billion yuan of the tertiary industry. Based on the permanent population, the per capita GDP is 36331 yuan [32].

\subsection{Data}

We used level-1 satellite imagery covering the study area from Landsat-7 Enhanced Thematic Mapper (ETM+) with 8 bands and Landsat- 8 Operational Land Imager (OLI) sensors with 11 bands [33], encompassing the years of 2004, 2009, 2014 and 2019 (Table 1). We used the cloud-free Landsat data downloaded from the United States Geological Survey (USGS) portal, in GeoTIFF format. We used GeoTiff format Indian Remote Sensing Satellite System Linear Imaging Self Scanning Sensor 3 (IRS LISS III) satellite imageries with 4 bands downloaded from the National Remote Sensing Centre (NRSC), Indian Space Research Organisation (ISRO). To standardize the coordinate reference system, we projected the 
satellite images to the Universal Transverse Mercator (UTM), using the World Geodetic System (WGS) 1984 datum.

Table 1. Landsat Enhanced Thematic Mapper (ETM+), Operational Land Imager (OLI) imageries and Linear Imaging Self Scanning Sensor- 3 (LISS III) used in this study.

\begin{tabular}{ccc}
\hline Date of Acquisition & Sensor Used & Spatial Resolution \\
\hline 06 June 2004 & Landsat-7 ETM+ & $30 \mathrm{~m}$ \\
03 June 2009 & Landsat-7 ETM+ & $30 \mathrm{~m}$ \\
12 June 2014 & Landsat-8 OLI & $30 \mathrm{~m}$ \\
03 June 2019 & Landsat-8 OLI & $30 \mathrm{~m}$ \\
23 June 2004 & LISS-III & $23.5 \mathrm{~m}$ \\
21 June 2009 & LISS-III & $23.5 \mathrm{~m}$ \\
26 June 2014 & LISS-III & $23.5 \mathrm{~m}$ \\
23 June 2019 & LISS-III & $23.5 \mathrm{~m}$ \\
\hline
\end{tabular}

\subsection{Research Design}

To summarize our research design, we provided a schematic representation for the methodological framework used in this study (Figure 2), which is described in the following subsections.

\subsection{Satellite Data Pre-Processing}

To assess the LULC dynamics in the study area, we followed the pre-processing technique (Figure 2) for the Landsat and IRS-LISS III imagery using geometrically corrections through the "georef" and "geoshift" functions in the "Landsat" package in R software [34] using ground control points (GCP) from USGS (https:/ / landsat.usgs.gov/gcp, accessed on 26 January 2019). The Landsat 7 Scan Line Corrector (SLC) has failed from 2003 [35]. Thus, data from 2004 and 2009 have data gaps, but are still beneficial and uphold the same geometric and radiometric corrections [35]. Therefore, we filled some missing data gaps (pixels) due to the scan line error happened in the ETM+ sensor in 2003, with the Landsat 7 Scan Line Corrector (SLC)-off Gap function [35,36]. After that, we rectified the SLC-off images by mosaicking according to the USGS gateway, filling the residual gaps through histogram correction [35]. We performed scan line error correction using the Earth Resource Development Assessment System (ERDAS), version 16.5 [37,38]. Using the Landsat ETM+ radiometric calibration of top-of-atmosphere (TOA) radiance [39], we transformed the digital number $(\mathrm{DN})$ integer values (0-255) of the raster data to at-satellite radiance values. In addition, we used an atmospheric correction to verify the disparity between surface reflectance and at-sensor reflectance [39]. We identify clouds, aerosol and cirrus, with dark object and modified dark object subtraction methods [40]. To ensure the homogeneousness of reflectance values for the examination of vegetation dynamics, we used invariant features in images across 2004-2019 through the pseudo-invariant features (PIF) function with a major axis regression [41,42]. We conducted all the atmospheric corrections and radiometric corrections in R software [43].

\subsection{Image Fusion}

The preprocessed Landsat-7/Landsat-8 and LISS III satellite sensor images were fused using the "Ehlers" image fusion technique to overcome the problem of spectral changes in agricultural areas and suburban lands [44]. Commonly, earth observation satellites sense the data as high-resolution panchromatic and low-resolution multispectral so image fusion is used to make use of better decisions [45]. Ehlers fusion helps us to preserve the spectral characteristics with minimal color distortion while doing multi-sensor and multi-data fusion [46]. It works by intensity-hue-saturation (IHS) transform which separates spectral and spatial information in a standard Red Green Blue (RGB) image [47]. We fused the high-resolution spatial structure from LISS III with the low-resolution spectral information from Landsat to construct a high-resolution multispectral image for land use and landcover 
classification. The idea of fusion algorithms is to sharpen the remotely sensed data by enhancing edges and grey level discontinuities without making changes on multispectral components in homogeneous areas [48]. Two things need to be taken care of to facilitate these requirements, as (i) optimal colour and spatial details must be separated and (ii) spatial information should be manipulated to allow adaptive enhancement of images [49].

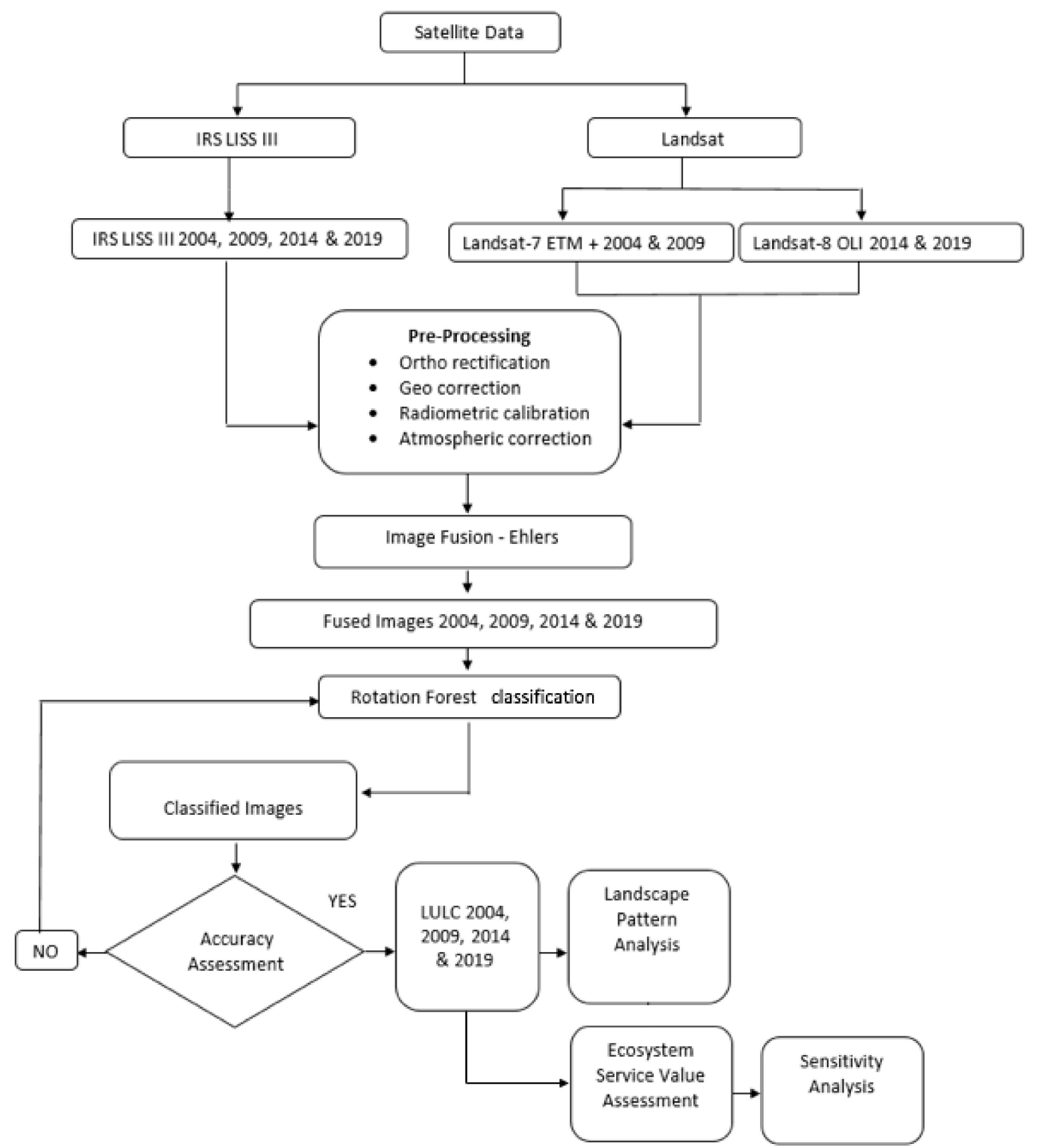

Figure 2. Methodology for analyzing ecosystem services and their economic values from land use and land cover changes.

The IHS transform is used for optimal colour separation similarly when the number of bands available is three, multiple IHS transform is employed until the number of bands available [48]. Since the spectral characteristics of every band varies, the order of bands must be specified for IHS transform [44]. Adaptive filter design can be obtained by the intensity component of the Fourier transform and the panchromatic image in the frequency domain. Spatial components are enhanced or suppressed using fast Fourier transform (FFT) [50]. Low pass filter is used for enhancing the intensity spectrum whereas high pass 
filter for enhancing the spectrum of high-resolution image [44]. Once filters are applied, inverse FFT is used to bring image back to spatial domain and fused to form new intensity component and consists of low frequency information from the low-resolution multispectral image and high frequency information from the high-resolution data generally panchromatic image [45]. A new IHS image is formed with the new intensity component and the hue and saturation component of the original multispectral image. Finally, a fused RGB image is obtained with spatial characteristics from panchromatic image and spectral characteristics from multispectral image by applying inverse IHS transform [44]. These steps are repeated until all the given bands are fused with panchromatic image. The order of a spectral bands in multiple IHS transform is not important because colour preservation procedures are employed in this fusion.

We used the "panSharpen" function of the "RStoolbox" package in R for the image fusion [26]. To avoid color distortion and damage of terrain feature information, we maintained all bands from Landsat-7/Landsat-8 and LISS III for the combining process [13]. We retained $23.5 \mathrm{~m}$ resolution in fused images for further classification and spatial metrics calculations.

\subsection{LULC Classification}

We divided the landscape into six LULC classes (woodland, grassland, farmland, built-up area, water and unused land; Table 2), using the rotation forest (RF) machine learning algorithm, based on the ensemble construction technique to acquire enhanced predictive performance (Figure 2) with less number of trees [26,51]. The RF algorithm is often connected with decision tree (DT) methods, where each LULC class should be individually reconstructed for image processing [51], through the following steps: (i) K subset is randomly split from the feature set; (ii) a principal component analysis (PCA) is applied in each of the subsets to find the variability information; (iii) the indeterminate occurrences are reclassified; (iv) the regular buoyancy is computed for each class through classifiers; and (v) the label of each classified class is reallocated to the one with the maximum buoyancy value. We perform this reclassification method in $\mathrm{R}$ software ( $\mathrm{R}$ Development Core Team, 2019).

Table 2. Description of land use/land cover (LULC) classes.

\begin{tabular}{ccc}
\hline & LULC Classes & Land Uses Comprised in the IDLULC \\
\hline 1 & Built-up area & Roads, man-made structures, and urban areas \\
2 & Woodland & Dense vegetation, forest and timberland \\
3 & Farmland & Agriculture and productive lands \\
4 & Unused land & Drylands, non-productive lands and non-irrigated \\
5 & Water bodies & Rivers, streams, lakes, open water, and ponds \\
6 & Grassland & Grazing area, bushes and shrubbery \\
\hline
\end{tabular}

We calculated and compared the accuracy of LULC between the non-fused and fused images of 2004, 2009, 2014 and 2019. We used Google Earth images from 2004, 2009, 2014 and 2019 of the Long country attained from Google Earth Engine (GEE) gateway [52] as a reference for the accuracy assessment of LULC maps from fused and non-fused images. We generated a group of random location points ( 25 for each class) and attained those values for 2004, 2009, 2014 and 2019. Then, the extracted random values from GEE images were compared to the classified LULC maps of 2004, 2009, 2014 and 2019. To examine the accuracy of classified LULC maps from fused and non-fused images, we employed the kappa coefficient using ERDAS Imagine 2018 (version 16.5). The producer and user accuracies were also computed using the confusion matrix classifier [53,54]. A kappa coefficient higher than 0.7 specifies an acceptable accuracy of classified LULC maps [54]. The accuracy rate is more than $85 \%$, also verified by actual field sampling. 


\subsection{Evaluation of Landscape Pattern}

\subsubsection{Selection of Landscape Metrics}

Landscape metrics is a quantitative index that can highly concentrate landscape pattern information and reflect characteristics of its structural composition and spatial configuration $[25,55,56]$. We used eleven landscape metrics to examine the landscape pattern information and characteristics of its structure and spatial configuration between 2004 and 2019 in Long County. Landscape metrics refers to a simple quantitative index that can provide very denser landscape pattern evidence at the patch level, landscapelevel and class-area level, which is suitable for quantitative expression of the relationship between landscape pattern and ecological process [25]. To examine the classification patterns of LULC, we selected the landscape metrics: patch type area (CA), patch area ratio (PLAND), number of patches (NP), clumpiness index (CLUMPY), average patch area (AREA_MN), patch density (PD), landscape shape index (LSI), and largest patch index (LPI). For illustrating different types of classes, complexity and spatial characteristics of fragmentation, we also used the landscape-level patch number (NP), Shannon diversity index (SHDI), landscape shape index (LSI), patch richness (PR), Shannon evenness index (SHEI), contagion index (CONTAG), and average patch area (AREA_MN) $[57,58]$ (see Table 3 for details). The different landscape metrics were computed in the FRAGSTATS software package (Version 4.2).

Table 3. Spatial metrics calculated to examine the landscape pattern information $[55,57,58]$.

\begin{tabular}{|c|c|c|c|}
\hline Landscape Metrics & Formulas & Explanation & Values Range \\
\hline Patch type area & $\begin{array}{c}C A=\sum_{j=1}^{n} a_{i j}\left(\frac{1}{10000}\right) \\
a_{i j}=\begin{array}{c}\text { area measures in } \mathrm{m}^{2} \text { of } \\
\text { patch covering } i j .\end{array}\end{array}$ & $\begin{array}{l}\text { To quantify the class area } \\
\text { in the landscape }\end{array}$ & $\mathrm{CA}>0$ \\
\hline Patch area ratio & $\begin{array}{c}\text { PLAND }=P_{i}=\frac{\sum_{j=1}^{n} a_{i j}}{100}(100) \\
P_{i}=\text { total landscape occupied } \\
\text { by different patch. } \\
a_{i j}=\begin{array}{c}\text { area measures in } \mathrm{m}^{2} \text { of } \\
\text { patch covering } i j .\end{array}\end{array}$ & $\begin{array}{l}\text { To quantifies landscape } \\
\text { patch region ratio }\end{array}$ & $0<$ PLAND $\leq 100$ \\
\hline Number of patches & $\begin{array}{c}N P=n_{i} \\
n_{i}=\text { total number of patches in the } \\
\text { region of patch type } i \text {. }\end{array}$ & $\begin{array}{l}\text { To measure the total } \\
\text { number of different } \\
\text { patches of LULC }\end{array}$ & $\mathrm{NP} \geq 1$ \\
\hline Landscape shape Index & $\begin{array}{c}L S I=\frac{e_{i}}{\min e_{i}} \\
e_{i}=\text { length of the different edges }\end{array}$ & $\begin{array}{c}\text { To measure class } \\
\text { aggregation for different } \\
\text { class area }\end{array}$ & LSI $1 \geq 1$, without limit \\
\hline Clumpiness Index & $\begin{array}{c}\text { Clumpy }=\left[\left(G_{i}-P_{i}\right) / P_{i}\right. \\
\text { for } G_{i}<P_{i} \& P_{i}<5 \text {, else } \\
\left.G_{i}-P_{i} / 1-P_{I}\right] \\
g_{i i}=\text { total number of similar } \\
\text { connections among pixels, } i \text { based } \\
\text { doubled progression and } g_{i k}=\text { total } \\
\text { number of similar connections among } \\
\text { pixels, } k \text { based doubled progression } \\
P_{i}=\text { total landscape occupied by } \\
\text { different patch. }\end{array}$ & $\begin{array}{l}\text { To quantity the } \\
\text { clumpiness of different } \\
\text { patches in the urban area. } \\
\text { Clumpiness shows the } \\
\text { frequency with which } \\
\text { various pairs of patch } \\
\text { types appear side-by-side } \\
\text { on the map }\end{array}$ & $-1 \leq \mathrm{CLUMPY} \leq 1$ \\
\hline Path Density & $\begin{array}{c}P D=\frac{n_{i}}{A}(10,000) \\
n_{i}=\text { total number of patches in the } \\
\text { region of patch type } i . \\
A=\text { total area in the landscape } \\
\text { measures in } \mathrm{m}^{2}\end{array}$ & $\begin{array}{c}\text { To calculate number of } \\
\text { patches of equivalent } \\
\text { patch type by total region }\end{array}$ & $\mathrm{PD}>0$ \\
\hline
\end{tabular}


Table 3. Cont.

\begin{tabular}{|c|c|c|c|}
\hline Landscape Metrics & Formulas & Explanation & Values Range \\
\hline Largest Patch Index & $\begin{array}{c}L P I=\frac{\max _{j=1}^{n}\left(a_{j i}\right)}{A}(100) \\
a_{i j}=\begin{array}{c}\text { area measures in } \mathrm{m}^{2} \text { of } \\
\text { patch covering } i j\end{array} \\
A=\text { total area in the landscape } \\
\text { measures in } \mathrm{m}^{2}\end{array}$ & $\begin{array}{l}\text { To measure the proportion } \\
\text { of the landscape } \\
\text { comprised by the } \\
\text { major patch }\end{array}$ & $0<\mathrm{LIP} \leq 100$ \\
\hline Average Patch area & $\begin{array}{c}M N=\frac{\sum_{j=1}^{n} X_{i j}}{n_{i}} \\
n_{i}=\text { total number of patches in the } \\
\text { region of patch type } i .\end{array}$ & $\begin{array}{l}\text { To examine the average } \\
\text { area of the } \\
\text { different patches }\end{array}$ & $0<\mathrm{MN} \leq 100$ \\
\hline Shannon evenness index & $\begin{array}{c}\text { SHEI }=\sum_{i}^{m}\left(P_{i} * \ln \left(P_{i}\right)\right) / \ln (m) \\
P_{i}=\text { total landscape occupied by } \\
\text { different patch. } \\
m=\text { total number of patch classes }\end{array}$ & $\begin{array}{l}\text { To provides information } \\
\text { on area richness } \\
\text { and composition }\end{array}$ & $0 \leq \mathrm{SHEI} \leq 1$ \\
\hline Shannon's diversity index & $\begin{array}{c}\text { SHDI }=\sum_{i=1}^{m}\left(P_{i} \ln \left(P_{i}\right)\right) \\
P_{i}=\text { total landscape occupied by } \\
\text { different patch. } \\
m=\text { total number of patch classes }\end{array}$ & $\begin{array}{l}\text { To provides information } \\
\text { on diversity }\end{array}$ & SHDI $\geq 1$ \\
\hline Contagion index & $\begin{array}{c}\text { Contag }=\left[1+\sum_{i=1}^{m} \sum_{k=1}^{m}\left[\left(p_{i}\right)\right.\right. \\
\left\{g_{i k} / \sum_{k=1}^{m} g_{i k}\right\} \\
\left\{\begin{array}{c}\left.\ln \left(p_{i}\right)\left[g_{i k} / \sum_{k=1}^{m} g_{i k}\right] / 2 \ln (m)\right] 100 \\
g_{i k}=\text { total number of similar }\end{array}\right. \\
\text { connections among pixels, } k \text { based } \\
\text { doubled progression } \\
P_{i}=\text { total landscape occupied by } \\
\text { different patch. } \\
m=\text { total number of patch classes }\end{array}$ & $\begin{array}{l}\text { To calculate the } \\
\text { heterogeneity }\end{array}$ & Percent $<$ Contagion $\leq 100$ \\
\hline
\end{tabular}

\subsubsection{Landuse Use Degree}

We also calculated the land use degree (LUD) to analyze the extent and complexity of regional land use, which can quantitatively reflect its natural attributes and the comprehensive consequence of human disturbance $[4,59] . L_{u}$ is mathematically defined as:

$$
L_{u}=100 \times \sum_{i=1}^{n} P_{i} \times Q_{i}
$$

where $L_{u}$ is the comprehensive index of land use degree; $P_{i}$ is the grade I land use degree grading index; $Q_{i}$ is the percentage of grade I land use grade area.

\subsection{Assessment of Ecosystem Services Values}

The assessment of ecosystem service values (ESV) is primarily based on the economic estimation for different types of ecosystems under a benefit transfer approach [60]. In this research, we propose an equivalent metric for estimating the value of ecosystem services [61], which also could be used in the whole of China. The calculation formula of the ESV coefficient [61] is as follows:

$$
V C_{0}=\frac{1}{7} \times P \times \frac{1}{n} \sum_{i=1}^{n} Q_{i}
$$


where $V C_{0}$ is the value of ESV equivalent factor (yuan $\mathrm{hm}^{-2} \mathrm{a}^{-1}$ ), (a is the equivalent factor for every year), yuan is the monetary unit of China ( $¥)$; $P$ is the average grain price (yuan $\times \mathrm{kg}^{-1}$ ) (different in each year); $Q$ is the average grain yield $\left(\mathrm{kg} \times \mathrm{hm}^{-2}\right.$ ) and $\mathrm{n}$ is the number of years. The value equivalent multiplied by the economic value of the natural grain output of the productive land quantifies the ecological value per unit area of the different landscape type. The formula for evaluating ESV [30] in Long County is:

$$
E V S=\sum_{k=1}^{n}\left(A_{k} \times V C_{k}\right)
$$

where $E S V$ measures in yuan; $A_{k}$ is the area in $\mathrm{hm}^{2}$ of landscape type $K$, and $V C_{k}$ is the ESV coefficient (yuan $\mathrm{hm}^{-2} \mathrm{a}^{-1}$ ).

For each land cover type, the services delivered by the ecosystem are identified and given a monetary value based on Long County socioeconomic situations as well as supply and demand. The assessed per square hectometer value of every ecosystem is then multiplied by the area of each biome to estimate the sum of the total monetary value of the Long County ecosystem [61].

\subsection{Sensitivity Analysis}

To verify whether the selected economic value (VC) was suitable for the study area, we used the standard economic elasticity concept to calculate the coefficient of sensitivity (CS) [62]. Sensitivity analysis helps to identify the impact of uncertainty in the coefficient values after obtaining the optimal solution of the model [62]. Sensitivity analysis is useful to regulate the dependence level of the change of the ESV upon the coefficient value [63].

The dependence of ESV and VC on time change can be determined by CS, which means that $1 \%$ change in VC cause $1 \%$ variation in ESV [62]. If CS $>1$, it indicates that the ESV is changeable to VC [61,64].; CS $<1$ specifies that the ESV is unchangeable to VC, thus VC is introduced appropriately, and the results are reliable [64]. The CS formula is as follows [63]:

$$
C S=\frac{\left(E S V_{j}-E S V_{i}\right) / E S V_{i}}{\left(V C_{j k}-V C_{j k}\right) / V C_{i k}}
$$

where CS is the sensitivity, refers to the change of ESV produced by $1 \%$ variation of $V C$. The $V C$ is the ecological value coefficient; $i$ and $j$ are the initial value coefficients and the adjusted coefficients; $k$ stands for different land uses [63].

\section{Results}

\subsection{Landscape Type Changes}

The LULC maps from 2004 to 2019 showed that farmland decreased their spatial distribution over time $\left(-42703 \mathrm{hm}^{2}\right)$ (Figure 3), reaching the pick in 2019. Grassland first increased and then decreased, with an overall change of $317 \mathrm{hm}^{2}$. Woodland also followed a similar pattern, with an overall change of $42,199 \mathrm{hm}^{2}$, whereas the built-up area increased $1487 \mathrm{hm}^{2}$. In general, the spatial distribution of water bodies also increased with a final gain of $906 \mathrm{hm}^{2}$. The overall unused land decreased, and the weakening trend slowed down in 2004, with an overall change of $-1717 \mathrm{hm}^{2}$.

We attained kappa coefficient values of $0.86,0.88,0.85$ and 0.86 with an overall accuracy value of $87 \%, 89 \%, 86 \%$ and $87 \%$ for the LULC classification for 2004, 2009, 2014 and 2019 respectively using fused images (Table 4 ). In contrast, the average kappa coefficient and overall accuracy values for LULC classification using non-fused images for 2004, 2009, 2014 and 2019 were considerably lower, i.e., $0.77,0.74,0.74,0.74$ and $76 \%, 75 \%, 75 \%$, and $75 \%$, respectively. Hence, the accuracy of LULC classification using non-fused images was significantly lower than the LULC classification using fused images. The accuracy of the LULC from the fused images is considerably higher because of the higher spatial resolution and number of bands available in fused images than non-fused images. Therefore, we used the LULC from fused images to calculate the ecosystem service and their economic values. 

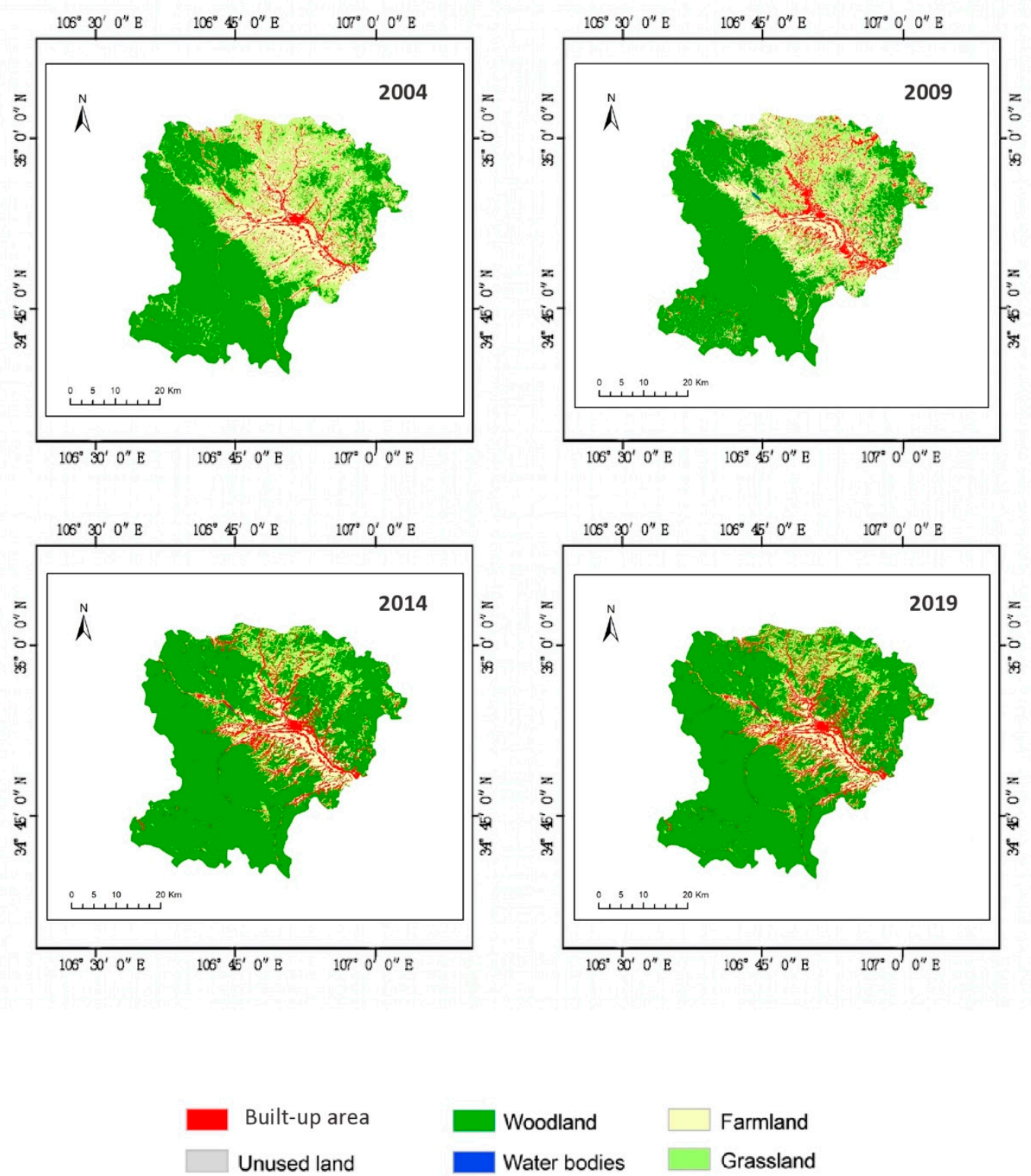

Figure 3. LULC change during the 15 years of the study period (2004-2019) in Long County, Shaanxi Province, China.

Table 4. Accuracy assessment values for the LULC using non-fused and fused images by 2004, 2009, 2014 and 2019. Producer accuracy $=$ PA; user accuracy $=$ UA.

\begin{tabular}{|c|c|c|c|c|c|c|c|c|c|c|c|c|c|c|c|c|}
\hline \multirow[b]{3}{*}{ Classes } & \multicolumn{4}{|c|}{2004} & \multicolumn{4}{|c|}{2009} & \multicolumn{4}{|c|}{2014} & \multicolumn{4}{|c|}{2019} \\
\hline & \multicolumn{2}{|c|}{ Non-Fused } & \multicolumn{2}{|c|}{ Fused } & \multicolumn{2}{|c|}{ Non-Fused } & \multicolumn{2}{|c|}{ Fused } & \multicolumn{2}{|c|}{ Non-Fused } & \multicolumn{2}{|c|}{ Fused } & \multicolumn{2}{|c|}{ Non-Fused } & \multicolumn{2}{|c|}{ Fused } \\
\hline & PA & UA & PA & UA & PA & UA & PA & UA & PA & UA & PA & UA & PA & UA & PA & UA \\
\hline Built-up area & 77.1 & 76.3 & 81.7 & 82.4 & 70.5 & 71.3 & 89.3 & 86.2 & 76.4 & 78.2 & 88.1 & 84.3 & 71.1 & 74.0 & 87.6 & 83.9 \\
\hline Woodland & 76.5 & 78.2 & 87.2 & 88.1 & 71.3 & 73.9 & 89.0 & 86.4 & 72.8 & 76.5 & 90.3 & 90.6 & 72.9 & 76.3 & 89.1 & 90.8 \\
\hline Farmland & 71.4 & 77.5 & 89.2 & 92.3 & 73.4 & 74.1 & 87.8 & 89.1 & 76.1 & 77.9 & 90.8 & 92.5 & 75.1 & 77.3 & 87.2 & 88.5 \\
\hline Unused land & 76.1 & 78.9 & 90.1 & 93.3 & 76.5 & 77.9 & 89.1 & 92.3 & 71.8 & 73.4 & 87.6 & 91.2 & 72.7 & 77.9 & 89.3 & 90.4 \\
\hline Water bodies & 78.7 & 79.8 & 87.6 & 88.9 & 77.1 & 75.4 & 90.1 & 92.3 & 76.3 & 79.5 & 80.1 & 81.5 & 80.1 & 81.8 & 82.4 & 85.9 \\
\hline Grassland & 80.1 & 81.2 & 90.6 & 94.5 & 82.4 & 83.1 & 92.6 & 93.1 & 80.4 & 81.5 & 82.3 & 83.8 & 80.5 & 80.9 & 89.9 & 93.2 \\
\hline Overall Accuracy & 76.5 & & 87.7 & & 75.2 & & 89.6 & & 75.6 & & 86.5 & & 75.4 & & 87.5 & \\
\hline Kappa & 0.77 & & 0.86 & & 0.74 & & 0.88 & & 0.74 & & 0.85 & & 0.74 & & 0.86 & \\
\hline
\end{tabular}


We obtained a transition matrix aiming to provide a quantitative description of the transitions in LULC between 2004 and 2019 for all estimated classes (Table 5). The transition matrix of the landscape area from 2004 to 2019 is presented in Table 6. It can be observed that most of the changes were transformed to farmland accounting for $86.45 \%$ of the total converted area. This spatial transformation trend was followed by woodland $(7 \%)$, unused land $(3.12 \%)$, built-up area $(2.58 \%)$, and grassland $(0.79 \%)$. The rest of the LULC types were marginally converted.

Table 5. Land area change and its respective percentage of each class of LULC during the study period (2004-2019).

\begin{tabular}{|c|c|c|c|c|c|c|c|c|c|c|c|c|}
\hline \multirow{2}{*}{$\begin{array}{c}\text { Landscape } \\
\text { Type }\end{array}$} & \multicolumn{2}{|c|}{2004} & \multicolumn{2}{|c|}{2009} & \multicolumn{2}{|c|}{2014} & \multicolumn{2}{|c|}{2019} & \multirow[b]{2}{*}{$\begin{array}{l}2004- \\
2009\end{array}$} & \multicolumn{3}{|c|}{ Change in Area $\left(\mathrm{hm}^{2}\right)$} \\
\hline & $\begin{array}{c}\text { Area } \\
\left(\mathrm{hm}^{2}\right)\end{array}$ & $\%$ & $\begin{array}{c}\text { Area } \\
\left(\mathrm{hm}^{2}\right)\end{array}$ & $\%$ & $\begin{array}{c}\text { Area } \\
\left(\mathrm{hm}^{2}\right)\end{array}$ & $\%$ & $\begin{array}{c}\text { Area } \\
\left(\mathrm{hm}^{2}\right)\end{array}$ & $\%$ & & $\begin{array}{l}2009- \\
2014\end{array}$ & $\begin{array}{l}2014- \\
2019\end{array}$ & $\begin{array}{l}2004- \\
2019\end{array}$ \\
\hline Farmland & 94,627 & 41.25 & 74,865 & 32.85 & 63,840 & 28.01 & 51,924 & 22.78 & -19762 & $-11,025$ & $-11,916$ & $-42,703$ \\
\hline Grassland & 481 & 0.21 & 1884 & 0.83 & 374 & 0.16 & 164 & 0.07 & 1403 & -1510 & -210 & -317 \\
\hline Woodland & 127,941 & 56.14 & 147,757 & 64.84 & 158,739 & 69.66 & 170,140 & 74.66 & 1,9816 & 10,982 & 11,401 & 42,199 \\
\hline Built-up area & 2989 & 1.31 & 2964 & 1.30 & 4271 & 1.87 & 4476 & 1.96 & -25 & 1307 & 205 & 1487 \\
\hline Water bodies & 104 & 0.05 & 376 & 0.16 & 248 & 0.11 & 1154 & 0.51 & 272 & -128 & 906 & 1050 \\
\hline Unused land & 1752 & 0.77 & 47 & 0.02 & 421 & 0.18 & 35 & 0.02 & -1705 & 374 & -386 & -1717 \\
\hline Total & 227,894 & 100 & 227,893 & 100 & 227,893 & 100 & 227,893 & 100 & - & - & - & - \\
\hline
\end{tabular}

Table 6. Landscape type area transition matrix from 2004 to 2019.

\begin{tabular}{|c|c|c|c|c|c|c|c|}
\hline \multirow[b]{2}{*}{$\begin{array}{c}\text { Landscape Types } \\
\text { in } 2004\end{array}$} & \multicolumn{7}{|c|}{ Landscape Types in 2019} \\
\hline & $\begin{array}{l}\text { Farm } \\
\text { Land } \\
\mathrm{hm}^{2}\end{array}$ & $\begin{array}{l}\text { Grass } \\
\text { Land } \\
\text { hm }^{2}\end{array}$ & $\begin{array}{l}\text { Wood } \\
\text { Land } \\
\text { hm }^{2}\end{array}$ & $\begin{array}{c}\text { Built-Up } \\
\text { Area } \\
\text { hm }^{2}\end{array}$ & $\begin{array}{c}\text { Water } \\
\text { Bodies } \\
\text { hm }^{2}\end{array}$ & $\begin{array}{c}\text { Unused } \\
\text { Land } \\
\text { hm }^{2}\end{array}$ & $\begin{array}{c}\text { Decreased } \\
\text { Ratio } \\
\%\end{array}$ \\
\hline Farm land & 512,109 & 60 & 503,241 & 28,041 & 7814 & 142 & 86.45 \\
\hline Grass land & 11,21 & 390 & 3765 & 60 & 5 & 1 & 0.79 \\
\hline Woodland & 38,564 & 1366 & $1,377,881$ & 1602 & 1906 & 243 & 7.00 \\
\hline Built-up area & 12,989 & - & 1537 & 17,097 & 1582 & 3 & 2.58 \\
\hline Water bodies & 108 & - & 58 & 122 & 868 & - & 0.05 \\
\hline Unused land & 12,046 & 2 & 3959 & 2816 & 647 & - & 3.12 \\
\hline New increased area $\left(\mathrm{hm}^{2}\right)$ & 64,828 & 1428 & 512,560 & 32,641 & 11,954 & 389 & - \\
\hline Increased proportion (\%) & 10.39 & 0.23 & 82.17 & 5.23 & 1.92 & 0.06 & 100 \\
\hline
\end{tabular}

\subsection{Estimation of LULC Changes}

Aggregate results for all LULC changes during the 15 years evaluated (2004-2019) are shown in Table 7. The results indicated that overall, the number of patches, patch density and landscape shape index contracted in $-1799,-0.7$ and -1.1 respectively. In contrast, the maximum patch index, mean patch area and spread degree increased $9.01 \%, 1209 \mathrm{hm}^{2}$ and 4 respectively. Landscape richness did not represent change, while Shannon diversity and uniformity slightly increased along the years.

Table 7. Aggregate changes on LULC in Long County during the 15 years (2004-2019), based on different landscape metrics.

\begin{tabular}{|c|c|c|c|c|c|c|c|c|c|}
\hline Year & $\begin{array}{l}\text { Number } \\
\text { of Patches }\end{array}$ & $\begin{array}{c}\text { Patch } \\
\text { Density }\end{array}$ & $\begin{array}{l}\text { Maximum } \\
\text { Patch Index }\end{array}$ & $\begin{array}{c}\text { Landscape } \\
\text { Shape Index }\end{array}$ & $\begin{array}{c}\text { Mean } \\
\text { Patch Area }\end{array}$ & $\begin{array}{l}\text { Contagion } \\
\text { Index }\end{array}$ & $\begin{array}{c}\text { Patch } \\
\text { Richness }\end{array}$ & $\begin{array}{c}\text { Shannon } \\
\text { Diversity } \\
\text { Index }\end{array}$ & $\begin{array}{c}\text { Shannon } \\
\text { Evenness } \\
\text { Index }\end{array}$ \\
\hline & (NP) & (PD) & (LPI \%) & (LSI) & $\left(\mathrm{hm}^{2}\right)$ & (Contag) & (PR) & (SHDI) & (SHEI) \\
\hline 2004 & 28,712 & 12.5989 & 44.0108 & 74.8318 & $18,088.33$ & 68.445 & 6 & 0.7998 & 0.44 \\
\hline 2009 & 26,857 & 11.7849 & 37.9496 & 79.0558 & $19,337.64$ & 69.3691 & 6 & 0.8011 & 0.44 \\
\hline 2014 & 27,836 & 12.2145 & 48.5861 & 85.6635 & $18,657.60$ & 70.0838 & 6 & 0.8197 & 0.45 \\
\hline 2019 & 26,913 & 11.8095 & 53.028 & 73.7931 & $19,297.53$ & 72.4943 & 6 & 0.8257 & 0.46 \\
\hline
\end{tabular}


When the analysis was expanded for the different categories of land use (i.e., woodland, farmland, built-up area, water, grassland, and unused land), the results showed an overall improvement for unused land, woodland, and grassland, while built-up area and farmland decreased their spatial representation. Indeed, the overall farmland for agriculture and unused land decreased, while woodland, grass and built-up area increased. The patch area ratio also followed a similar trend. In the half of the first decade (2004-2009), the landscape shape index declined for woodland (3.7\%) and farmland (3.5\%), while stabilized in the following years. Landscape shape index did not change for grassland during all the 15 years assessed, showing an increase for built-up area and a decrease for unused land, despite slight stabilization between 2004 and 2009 (Table 8).

Table 8. Change on LULC in Long County during the 15 years (2004-2019), based on different landscape metrics.

\begin{tabular}{|c|c|c|c|c|c|c|c|c|c|}
\hline \multirow{2}{*}{ Landscape Type } & \multirow{2}{*}{ Year } & $\begin{array}{c}\text { Patch } \\
\text { Type Area }\end{array}$ & $\begin{array}{c}\text { Patch Area } \\
\text { Ratio }\end{array}$ & $\begin{array}{c}\text { Number of } \\
\text { Patches }\end{array}$ & $\begin{array}{c}\text { Patch } \\
\text { Density }\end{array}$ & $\begin{array}{c}\text { Max Patch } \\
\text { Index }\end{array}$ & $\begin{array}{l}\text { Landscape } \\
\text { Shape Index }\end{array}$ & $\begin{array}{c}\text { Mean } \\
\text { Patch Area }\end{array}$ & Concentration \\
\hline & & $\begin{array}{c}\mathrm{CA} \\
\mathrm{km}^{2}\end{array}$ & PLAND \% & NP & PD & LPI & LSI & $\begin{array}{l}\mathrm{MN} \\
\mathrm{km}^{2}\end{array}$ & CLUMPY \\
\hline \multirow{4}{*}{ Woodland } & 2004 & $127,940.5$ & 56.14 & 8477 & 3.72 & 44.01 & 78.72 & $34,395.21$ & 0.85 \\
\hline & 2009 & $147,756.8$ & 64.84 & 9601 & 4.21 & 37.95 & 82.25 & $35,072.06$ & 0.82 \\
\hline & 2014 & $158,739.3$ & 69.66 & 7471 & 3.28 & 48.59 & 89.69 & $48,421.35$ & 0.78 \\
\hline & 2019 & $170,139.6$ & 74.66 & 6291 & 2.76 & 53.03 & 70.80 & $61,633.45$ & 0.80 \\
\hline \multirow{4}{*}{ Grassland } & 2004 & 480.78 & 0.21 & 1806 & 0.79 & 0.01 & 46.10 & 606.65 & 0.37 \\
\hline & 2009 & 1884.42 & 0.83 & 5520 & 2.42 & 0.02 & 86.82 & 778.03 & 0.40 \\
\hline & 2014 & 374.13 & 0.16 & 1025 & 0.45 & 0.01 & 34.27 & 831.81 & 0.47 \\
\hline & 2019 & 163.62 & 0.07 & 730 & 0.32 & 0.00 & 29.51 & 510.71 & 0.31 \\
\hline \multirow{4}{*}{ Farm land } & 2004 & $94,626.63$ & 41.52 & 6496 & 2.85 & 35.70 & 108.75 & $33,196.95$ & 0.82 \\
\hline & 2009 & $74,865.06$ & 32.85 & 7628 & 3.35 & 27.20 & 126.88 & $22,366.56$ & 0.79 \\
\hline & 2014 & $63,840.24$ & 28.01 & 11276 & 4.95 & 16.49 & 148.65 & $12,902.39$ & 0.76 \\
\hline & 2019 & $51,924.33$ & 22.78 & 8765 & 3.85 & 7.18 & 137.17 & $13,500.61$ & 0.77 \\
\hline \multirow{4}{*}{ Built-up area } & 2004 & 2988.72 & 1.31 & 3250 & 1.43 & 0.19 & 65.30 & 2095.70 & 0.64 \\
\hline & 2009 & 2964.24 & 1.30 & 3546 & 1.56 & 0.14 & 72.34 & 1904.96 & 0.60 \\
\hline & 2014 & 4270.86 & 1.87 & 6759 & 2.97 & 0.53 & 91.01 & 1440.06 & 0.58 \\
\hline & 2019 & 4476.42 & 1.96 & 7387 & 3.24 & 0.46 & 96.96 & 1381.03 & 0.56 \\
\hline \multirow{4}{*}{ Water bodies } & 2004 & 104.04 & 0.05 & 187 & 0.08 & 0.02 & 11.46 & 1268.00 & 0.68 \\
\hline & 2009 & 375.93 & 0.17 & 475 & 0.21 & 0.04 & 23.36 & 1803.55 & 0.65 \\
\hline & 2014 & 247.86 & 0.11 & 359 & 0.16 & 0.04 & 18.33 & 1573.37 & 0.66 \\
\hline & 2019 & 1153.98 & 0.51 & 3703 & 1.62 & 0.04 & 64.53 & 710.11 & 0.43 \\
\hline \multirow{4}{*}{ Unused land } & 2004 & 1752.30 & 0.77 & 8496 & 3.73 & 0.01 & 101.41 & 469.92 & 0.27 \\
\hline & 2009 & 46.53 & 0.02 & 87 & 0.04 & 0.00 & 14.13 & 1218.77 & 0.39 \\
\hline & 2014 & 420.57 & 0.18 & 946 & 0.42 & 0.00 & 34.56 & 1013.21 & 0.50 \\
\hline & 2019 & 35.01 & 0.02 & 37 & 0.02 & 0.01 & 6.40 & 2156.32 & 0.71 \\
\hline
\end{tabular}

In general, the maximum patch index and mean patch area increased for woodland and grassland LULC types, despite a slight decrease in the last quarter of the study period. Whereas farmland and unused land followed an inverse trend. The built-up area slightly increased in the first quarter (2004-2009), decreased in the second quarter (2009-2014) and stabilized for the rest of the period (2014-2019), considering the maximum patch index (Table 8). However, concerning the mean patch area, a consistent trend of increment during all period was observed. The water bodies showed an oscillatory trend during the study period for both maximum patch and mean patch area indices.

\subsection{Ecosystem Services Value}

Our results on the ecosystem services valuation showed that the ESV tended to increase during the past 15 years, with an overall increase of $10016.1 \times 10^{5}$ yuan, showing an equivalent increment of $27.8 \%$. (Table 9). On the one hand, from the perspective of the annual change rate, this upward trend still not relevant for the landscape dynamics along the years evaluated. On the other hand, the ESV of all landscape types increased from 2004 to 2019, except for farmland, grassland, and unused land in which the overall values declined. Among the assessed landscape types, the ESV of woodland had an increment of 
$32.9 \%$ on its area, which equivalent to $10462.2 \times 10^{5}$ yuan. The value of water ES increased by $1009.1 \%$, equivalent to $1424.7 \times 10^{5}$ yuan. The ESV of grassland decreased by $65.9 \%$ and represents $17.2 \times 10^{5}$ yuan, which was also considered the largest decrease among all landscape types during the studied period. However, the ESV of farmland decreased by $45.1 \%$ equivalent to $1849.8 \times 10^{5}$ yuan. The ESV of unused land was the most decreased, reaching $97.8 \%$, and showing an equivalent decline of $3.7 \times 10^{5}$ yuan.

Table 9. Value and change of ecosystem services in the landscape types from 2004 to 2019.

\begin{tabular}{|c|c|c|c|c|c|c|c|c|c|c|c|c|}
\hline \multirow[b]{2}{*}{$\begin{array}{c}\text { Landscape } \\
\text { Type }\end{array}$} & \multicolumn{4}{|c|}{$\mathrm{ESV} / \times 10^{5}(\mathrm{RMB} / \mathrm{a})$} & \multicolumn{2}{|c|}{ 2004-2009 } & \multicolumn{2}{|c|}{ 2009-2014 } & \multicolumn{2}{|c|}{ 2014-2019 } & \multicolumn{2}{|c|}{ 2004-2019 } \\
\hline & 2004 & 2009 & 2014 & 2019 & $\begin{array}{l}\text { Change } \\
\left(\times 10^{5}\right. \\
\text { Yuan })\end{array}$ & $\begin{array}{c}\text { Rate } \\
\%\end{array}$ & $\begin{array}{c}\text { Change } \\
\left(\times 10^{5}\right. \\
\text { Yuan })\end{array}$ & $\begin{array}{c}\text { Rate } \\
\%\end{array}$ & $\begin{array}{l}\text { Change } \\
\left(\times 10^{5}\right. \\
\text { Yuan })\end{array}$ & $\begin{array}{c}\text { Rate } \\
\%\end{array}$ & $\begin{array}{c}\text { Change } \\
\left(\times 10^{5}\right. \\
\text { Yuan })\end{array}$ & $\underset{\%}{\text { Rate }}$ \\
\hline Woodland & $31,719.7$ & $36,632.7$ & $39,355.5$ & $42,181.9$ & 4912.9 & 15.4 & 2722.8 & 7.43 & 2826.4 & 7.1 & $10,462.2$ & 32.9 \\
\hline Grassland & 26.1 & 102.6 & 20.3 & 8.91 & 76.4 & 291.9 & -82.2 & -80.1 & -11.4 & -56.2 & -17.2 & -65.9 \\
\hline Farmland & 4099.1 & 3243.1 & 2765.5 & 2249.3 & -856.06 & -20.8 & -477.5 & -14.7 & -516.1 & -18.6 & -1849.8 & -45.1 \\
\hline $\begin{array}{l}\text { Water } \\
\text { bodies }\end{array}$ & 141.1 & 510.1 & 336.3 & 1565.8 & 368.9 & 261.3 & -173.7 & -34.0 & 1229.5 & 365.5 & 1424.7 & 1009.1 \\
\hline $\begin{array}{c}\text { Unused } \\
\text { land }\end{array}$ & 3.7 & 0.10 & 0.91 & 0.08 & -3.6 & -97.3 & 0.8 & 810.0 & -0.8 & -91.21 & -3.7 & -97.8 \\
\hline Total & $35,990.06$ & $40,488.6$ & $42,478.6$ & $46,006.1$ & 4498.5 & 12.5 & 1990.0 & 4.9 & 3527.5 & 8.30 & $10,016.1$ & 27.8 \\
\hline
\end{tabular}

\subsection{Changes in Individual Ecosystem Services Value}

Table 10 presents the changes on the ESV of each service, showing that the food production values experienced the largest decline, with a decrease of $251.8 \times 10$ yuan, corresponding to $19.76 \%$ of their spatial representativeness, while the largest increase in value was for biodiversity, with an increment of $1065.31 \times 10$ yuan $(30.7 \%)$. A higher change was observed from 2004 to 2009. This change was observed for all individual services, among which the value of water conservation service increased up to $3192.1 \times 10$ yuan. While in contrast, from 2004 to 2019, the variation trend of the value of every single function was weakened. After 2014, the change rate of the value of each single ES was the lowest and the fluctuation was the least. From the perspective of the overall individual composition of the research area, the values of each ecosystem service can be ranked as soil formation and protection $>$ water conservation $>$ biodiversity conservation $>$ gas regulation $>$ climate regulation $>$ waste treatment $>$ raw materials $>$ entertainment culture $>$ food production. Values of soil formation and protection services were the maximum, accounting for $15.7 \%$ of the complete ecosystem service values, followed by the service of water conservation, accounting for $45.9 \%$ of the overall service values. Overall, the biodiversity conservation, gas adjustment and climate regulation services, when combined, accounted for $79.4 \%$ of the total ecosystem service values, in which food production was responsible for the overall proportion of $19.7 \%$ of the values.

\subsection{Sensitivity Analysis}

All landscape types of ESV had a CS lower than 50\%, except for the woodland class (Figure 4). It can be observed that among all landscape classes, woodland showed the highest CS from 2004 to 2019, with a maximum sensitivity index higher than 0.51, which was increased year by year. The CS of each landscape type in the study area was lower than 1 , indicating that the CS value adopted is inelastic and applicable to the real state of the study area, suggesting that the estimated results of ecosystem service values are credible. 
Table 10. Changes in the ecosystem service value (ESV) during the 15 years of study period (2004-2019) in Long County, Shaanxi Province, China.

\begin{tabular}{|c|c|c|c|c|c|c|c|c|c|c|c|c|}
\hline \multirow[b]{2}{*}{$\begin{array}{c}\text { Ecosystem } \\
\text { Services }\end{array}$} & \multicolumn{4}{|c|}{$\mathrm{ESV} / \times 10^{5}$ (yuan/a) } & \multicolumn{2}{|c|}{ 2004-2009 } & \multicolumn{2}{|c|}{ 2009-2014 } & \multicolumn{2}{|c|}{ 2014-2019 } & \multicolumn{2}{|c|}{ 2004-2019 } \\
\hline & 2004 & 2009 & 2014 & 2019 & $\begin{array}{c}\text { Change } \\
\left(\times 10^{5}\right. \\
\text { Yuan) }\end{array}$ & $\begin{array}{c}\text { Rate } \\
\%\end{array}$ & $\begin{array}{c}\text { Change } \\
\left(\times 10^{5}\right. \\
\text { Yuan })\end{array}$ & $\begin{array}{c}\text { Rate } \\
\%\end{array}$ & $\begin{array}{c}\text { Change } \\
\left(\times 10^{5}\right. \\
\text { Yuan })\end{array}$ & $\begin{array}{c}\text { Rate } \\
\%\end{array}$ & $\begin{array}{c}\text { Change } \\
\left(\times 10^{5}\right. \\
\text { Yuan })\end{array}$ & $\begin{array}{c}\text { Rate } \\
\%\end{array}$ \\
\hline $\begin{array}{c}\text { Gas } \\
\text { conditioning }\end{array}$ & 3688.0 & 4019.1 & 4187.4 & 4374.7 & 331.13 & 8.98 & 168.35 & 4.19 & 187.30 & 4.47 & 686.78 & 18.62 \\
\hline $\begin{array}{l}\text { Climate } \\
\text { regulation }\end{array}$ & 9361.3 & 1070.3 & $11,406.2$ & $12,179.8$ & 1341.67 & 14.3 & 703.27 & 6.57 & 773.54 & 6.78 & 2818.48 & 30.11 \\
\hline $\begin{array}{c}\text { Water } \\
\text { conservation }\end{array}$ & 6947.6 & 8218.9 & 8592.28 & $10,139.7$ & 1271.22 & 18.3 & 373.38 & 4.54 & 1547.51 & 18.0 & 3192.11 & 45.94 \\
\hline $\begin{array}{l}\text { Soil formation } \\
\text { and protection }\end{array}$ & 4720.1 & 5079.3 & 5259.76 & 5461.14 & 359.17 & 7.61 & 180.41 & 3.55 & 201.38 & 3.83 & 740.96 & 15.70 \\
\hline Waste disposal & 500.10 & 594.18 & 619.36 & 739.62 & 94.08 & 18.8 & 25.18 & 4.24 & 120.26 & 19.4 & 239.52 & 47.89 \\
\hline $\begin{array}{l}\text { Biodiversity } \\
\text { conservation }\end{array}$ & 3469.9 & 3973.7 & 4231.60 & 4535.27 & 503.78 & 14.5 & 257.86 & 6.49 & 303.67 & 7.18 & 1065.31 & 30.70 \\
\hline $\begin{array}{c}\text { Food } \\
\text { production }\end{array}$ & 1271.1 & 1155.6 & 1086.06 & 1019.96 & -115.52 & -9.09 & -69.56 & -6.02 & -66.10 & -6.09 & -251.18 & -19.76 \\
\hline Raw materials & 1322.0 & 1380.7 & 1408.84 & 1440.56 & 58.70 & 4.44 & 28.06 & 2.03 & 31.72 & 2.25 & 118.48 & 8.96 \\
\hline $\begin{array}{l}\text { Entertainment } \\
\text { culture }\end{array}$ & 1530.0 & 1753.2 & 1865.23 & 2005.94 & 223.26 & 14.5 & 111.97 & 6.39 & 140.71 & 7.54 & 475.94 & 31.11 \\
\hline Aggregate & $32,810.4$ & $36,877.9$ & $38,656.8$ & $41,896.8$ & 4067.48 & 12.4 & 1778.9 & 4.82 & 3240.01 & 8.38 & 9086.41 & 27.69 \\
\hline
\end{tabular}

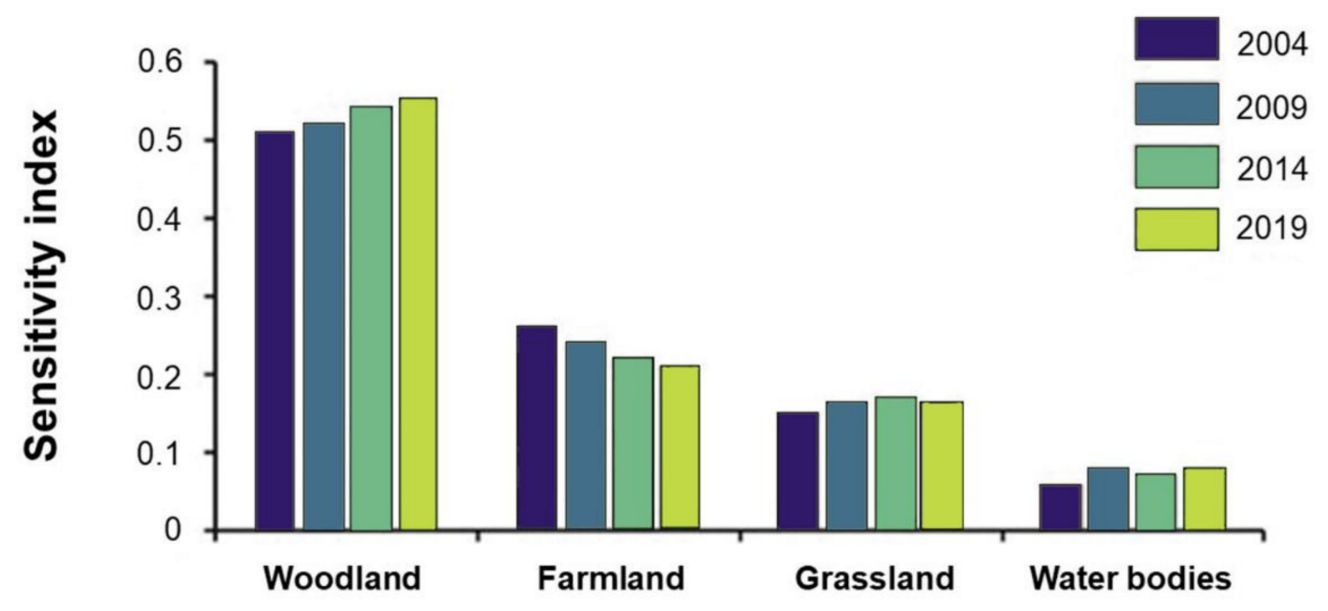

\section{Landscape type}

Figure 4. Changes on the sensitivity index for the landscape types from 2004 to 2019.

\section{Discussion}

Our findings showed an overall improvement in the spatial distribution of the landscape types and ES evaluated during the 15 years of the study period. With woodland and grassland accounting most for the improvement, whereas the transformation of farmland and grassland into built-up area reduced the landscape cover, ES provisioning and amenity. The results are in accordance with some other studies conducted in China [30,65]. The observed pattern over urban areas can be attributed to increasing middle-class demands in China, which is directly correlated to housing building in cities, hence stimulating the construction booming [59]. In fact, in countries like China, farmland is not only primarily targeted for agriculture, but also housing [25], as they're also better conditions for water supply and settlement patterns.

Overall, evenness and connectivity in Long County improved over the last 15 years, which can be observed by the decline of fragmentation and the degree of landscape dominance, also resulted from an improvement of the patches and the maximum patch 
index, which lead the enhancement of spreading degree, Shannon diversity and Shannon evenness index here observed. This improvement in landscape and biodiversity indicators can be mostly attributed to the growth of woodlands and grasslands during 2004-2019, especially in the first third (2004-2009) (see Figure 3; Table 6). These kinds of landscape transformations can alter the species-area relationships, which represent complementary habitats for several species and can support ecological connectivity, thus contributing to the biological community structure [66]. This general pattern can also be highlighted by the higher increment on the sensitivity index for woodland, as well as the gradual increase on the LULC during the study period.

Most of woodlands and grasslands were converted from the farm, water and unused lands. That is a good signal, in the sense that one can infer that this efficient allocation undoubtedly improved or will improve most of the provisioning services (e.g., nutrition, water provisioning and biomass energy) and regulating and maintenance (e.g., regulating wastes, flow, physical and biotic environment). Based on the ESV, the overall value of ES increased $(4.34 \%)$, with woodland and grassland contributes to this gain. Those results are also in line with the proposed by Zhang et al. [16], who found that the implemented payments for ecosystem services (PES) programs by the Chinese government, notably the Conversion of Cropland to Forest Program (CCFP) and the Ecological Welfare Forest Program (EWFP), provided poor rural farmers with large areas of forest with sizable cash subsidies, which reduce their motivation to migrate and to transform the forest into croplands.

The conversion of farmland, grassland and water yield into built-up area is inevitable in a fast-developing economy, with high population density and fast growth middle-class demands. For instance, a related study showed that the considerable urban expansion and consequent growth in GDP in four ecoregions in the Hang-Jia-Hu region (China), led to a loss of 8.5 billion RMB yuan ESV per year on average between 1994 and 2003 [25]. Another previous research in China also observed that the ratio of ESV per capita to the GDP per capita was about 0.87 , and such ratio was lowest in the most economically developed and densely populated areas [31]. Thus, the conversion of forest and agricultural land into urban areas must be done through less environmental impact. For instance, by taking into account the new standards of environmentally friendly cities and smart cities, which also prioritizes the use of clean energies, the construction of buildings that are energy efficient and provide the expansion of green areas [2]. Here, we have noticed that there was a significant unused land that was converted into woodland and grassland, while simultaneously other woodland and grassland were converted into built-up area. It also would be more beneficial for ES enhancement, transferring unused land into built-up area while maintaining the forest land.

The overall enhancement on the ESV was mostly due to the increase on the woodland, grassland and water body with total accounted for $4.34 \%$ of the ESV, equivalent to $64.873 \times 10$ yuan, during the study period. A previous study found a decrease of $231.3 \mathrm{mil}-$ lion Yuan from 1996 to 2004 in Shenzhen, one of the fastest-growing metropolitan areas in China, mainly due to the decreasing areas of woodland and water bodies [14]. While in the present study, the increase of ESV was mostly due to the transformation of farmland into grass and woodland. It is important to notice that, farmland can sometimes provide more valuable ES depending on the agricultural system and the type of crops that are allocated [24]. For this specific case, the conversion of one unit of farmland into grass or woodland add more value into the ESV, than the opposite. It means that the type of agriculture system and their resulting output need to be improved into more environmentally friendly practices, by understanding the optimal trade-off between the transformation of grassland and woodland into farmland and other land uses, such as water body. However, the local and central government plays a key role in identity and promote environmentally friendly agriculture production by proved the required incentives that internalize the positive externalities while externalizing negative externalities. 
Despite the observed increment on the ESV of grassland, it is important to highlight that grassland is a fire-prone ecosystem that can easily burn and spread faster, hence results on the release of greenhouse gases and the subsequent soil impoverishment and the degradation of macrofauna [66]. In such circumstances, the relative gain on ESV can be easily converted in disservices. In that regarding, the government need to ensure that most of the grassland can be converted into woodland, before fire occurrence, since there is considerable potential for this conversion, based on the transition matrix (see Table 6).

ESV increased during the study period (2004-2019) because most of the farmland (agriculture) was converted into woodland and grassland. The enhancement of ESV can also be attributed to government policy, that aim to restore forest landscape and its environmental management to prevent soil erosion and habitat loss [16,19], since areas with larger slope are not suitable for farming, which shall be converted to woodland and grassland [21]. Most of the unused land was converted into water bodies, thus this land class was efficiently converted. As a result, the overall ES was gradually improved. With human intervention, the proportion of patch area and the maximum patch index of built-up area gradually increase over the years, while the aggregation degree of water and the landscape shape index decreased, indicating that under the intervention of anthropogenic activities, the degree of water conservation in the area is higher, while the unused land is maximized.

The values of soil formation and protection service were the highest, followed by the service of water conservation, biodiversity conservation, gas adjustment and climate regulation service function. While food production accounted for the lowest proportion of the overall service value. The main purpose is that the increase of woodland and grassland improves the regional ecosystem functioning, which directly affected the services of soil formation and protection, and water conservation. Therefore, the food production capacity is weakened, resulting in a decline in the value of food production services in the region.

\section{Conclusions}

We validated the benefits of using LULC from fused satellite imageries in evaluating land use changes on ES and their economic values in fast-developing county like Long County. Our findings showed that the overall spatial patterns of LULC were improved during the study period, especially from 2014 to 2019, with the conversion of farmland and unused land into woodland and grassland accounting for most of this improvement. This suggests improved conservation outcomes of landscape connectivity, uniformity and biodiversity in that period. The total ESV in the study area was also higher compared to the national average, despite the expansion of the built-up area, which was probably related to the existing of government policies that stimulating the enhancement of ES by providing a financial incentive.

We also examined the landscape pattern information and characteristics of its structure and spatial configuration between 2004 and 2019 in Long County. Even though this research didn't establish a direct relationship between pattern and ESV, we provided landscape pattern evidence at the patch level, landscape-level, and class-area level, which is suitable for quantitative expression of the relationship between landscape pattern and ecological process. We particularly recommend studying the relationship between landscape pattern and ESV in the future.

The analysis conducted in this study highlights the importance of understanding the causes of drivers and underlying drivers of LULC change to assess the impacts of those changes and define development policies. The implementation of development models at the landscape level must balance the economic benefits and ecological gains of the different land cover classes to enhance their ESV, requiring an interdisciplinary and science-based approach.

Author Contributions: Conceptualization, W.S., R.P., M.S. and A.A.M.; methodology, W.S., A.A.M. and R.P.; formal analysis, W.S., M.S. and R.P.; investigation, W.S., R.P. and A.A.M.; writing-original draft preparation, W.S., R.P. and M.S.; writing-review and editing, W.S., R.P., J.M.N.S., P.C. and F.S.C.; supervision, R.P., P.C. and F.S.C.; All authors have read and agreed to the published version of the manuscript. 
Funding: This study was supported by the Research on Capitalization of Natural Resources and Corresponding Market Construction in China [grant number 15ZDB162]; and partially through the FCT (Fundação para a Ciência e a Tecnologia) under the projects PTDC/CTA-AMB/28438/2017ASEBIO and UIDB/04152/2020 - Centro de Investigação em Gestão de Informação (MagIC). This research was also funded by the Forest Research Centre, a research unit funded by Fundação para a Ciência e a Tecnologia I.P. (FCT), Portugal (UIDB/00239/2020).

Institutional Review Board Statement: Not applicable.

Informed Consent Statement: Not applicable.

Data Availability Statement: Samples of data are available from the authors.

Acknowledgments: The authors would like to thank the financial support provided by Research on Capitalization of Natural Resources and Corresponding Market Construction in China and Fundação para a Ciência e Tecnologia (FCT).

Conflicts of Interest: The authors declare no conflict of interest.

\section{References}

1. Garcia-Gonzalo, J.; Bushenkov, V.; McDill, M.E.; Borges, J.G. A decision support system for assessing trade-offs between ecosystem management goals: An application in portugal. Forests 2015, 6, 65-87. [CrossRef]

2. Jin, J.; Jiang, C.; Li, L. The economic valuation of cultivated land protection: A contingent valuation study in Wenling City, China. Landsc. Urban Plan. 2013, 119, 158-164.

3. Schmiedel, U.; Linke, T.; Christiaan, R.; Falk, T.; Grongroft, A.; Haarmeyer, D.; Hanke, W.; Henstock, R.; Hoffman, T.; Kunz, N.; et al. Environmental and socio-economic patterns and processes in the Succulent Karoo-Frame conditions for the management of this biodiversity hotspot. Biodivers. S. Afr. Implic. Landuse Manag. 2010, 3, 109-150.

4. Maloney, K.O.; Feminella, J.W.; Mitchell, R.M.; Miller, S.A.; Mulholland, P.J.; Houser, J.N. Landuse legacies and small streams: Identifying relationships between historical land use and contemporary stream conditions. J. N. Am. Benthol. Soc. 2008, 27, 280-294. [CrossRef]

5. Sharp, R.; Tallis, H.T.; Ricketts, T.; Guerry, A.D.; Wood, S.A.; Chaplin-Kramer, R.; Nelson, E.; Ennaanay, D.; Wolny, S.; Olwero, N.; et al. InVEST User Guide. 2018. Available online: http:/ / data.naturalcapitalproject.org/nightly-build/invest-users-guide/html/ (accessed on 9 May 2019).

6. Zhao, J.; Liu, Q.; Lin, L.; Lv, H.; Wang, Y. Assessing the comprehensive restoration of an urban river: An integrated application of contingent valuation in Shanghai, China. Sci. Total Environ. 2013, 458-460, 517-526. [CrossRef] [PubMed]

7. Tallis, H.; Goldman, R.; Uhl, M.; Brosi, B. Integrating conservation and development in the field: Implementing ecosystem service projects. Front. Ecol. Environ. 2009, 7, 12-20. [CrossRef]

8. Xu, C.; Pu, L.; Zhu, M.; Li, J.; Chen, X.; Wang, X.; Xie, X. Ecological security and ecosystem services in response to land use change in the coastal area of Jiangsu, China. Sustainability 2016, 8, 816. [CrossRef]

9. Ninan, K.N.; Inoue, M. Valuing forest ecosystem services: What we know and what we don't. Ecol. Econ. 2013, 93, 137-149. [CrossRef]

10. Barral, M.P.; Rey Benayas, J.M.; Meli, P.; Maceira, N.O. Quantifying the impacts of ecological restoration on biodiversity and ecosystem services in agroecosystems: A global meta-analysis. Agric. Ecosyst. Environ. 2015, 202, 223-231. [CrossRef]

11. Boyd, J.; Banzhaf, S. What are ecosystem services? The need for standardized environmental accounting units. Ecol. Econ. 2007, 63, 616-626. [CrossRef]

12. Jat, M.K.; Garg, P.K.; Khare, D. Monitoring and modelling of urban sprawl using remote sensing and GIS techniques. Int. J. Appl. Earth Obs. Geoinf. 2008, 10, 26-43. [CrossRef]

13. Tianhong, L.; Wenkai, L.; Zhenghan, Q. Variations in ecosystem service value in response to land use changes in Shenzhen. Ecol. Econ. 2010, 69, 1427-1435. [CrossRef]

14. Gan, L.; Yu, J. Bioenergy transition in rural China: Policy options and co-benefits. Energy Policy 2008, 36, 531-540. [CrossRef]

15. Zhang, Q.; Bilsborrow, R.E.; Song, C.; Tao, S.; Huang, Q. Determinants of out-migration in rural China: Effects of payments for ecosystem services. Popul. Environ. 2018, 40, 182-203. [CrossRef]

16. Burgos, S.; Ear, S. China's oil hunger in Angola: History and perspective. J. Contemp. China 2012, 21, 351-367. [CrossRef]

17. Rao, Y.; Zhou, M.; Ou, G.; Dai, D.; Zhang, L.; Zhang, Z.; Nie, X.; Yang, C. Integrating ecosystem services value for sustainable land-use management in semi-arid region. J. Clean. Prod. 2018, 186, 662-672. [CrossRef]

18. Fu, B.; Zhu, Y.; Wang, S. Earth surface processes and environmental sustainability in China: Preface. Earth Environ. Sci. Trans. R. Soc. Edinb. 2019, 109, 373-374. [CrossRef]

19. Wang, J.; Peng, J.; Zhao, M.; Liu, Y.; Chen, Y. Significant trade-off for the impact of Grain-for-Green Programme on ecosystem services in North-western Yunnan, China. Sci. Total Environ. 2017, 574, 57-64. [CrossRef]

20. Wang, X.; Zhang, X.; Feng, X.; Liu, S.; Yin, L.; Chen, Y. Trade-offs and Synergies of Ecosystem Services in Karst Area of China Driven by Grain-for-Green Program. Chin. Geogr. Sci. 2020, 30, 101-114. [CrossRef] 
21. Pei, S.; Zhang, C.; Liu, C.; Liu, X.; Xie, G. Forest ecological compensation standard based on spatial flowing of water services in the upper reaches of Miyun Reservoir, China. Ecosyst. Serv. 2019, 39, 100983. [CrossRef]

22. Andersen, E. The farming system component of European agricultural landscapes. Eur. J. Agron. 2017, 82, 282-291. [CrossRef]

23. Su, S.; Xiao, R.; Jiang, Z.; Zhang, Y. Characterizing landscape pattern and ecosystem service value changes for urbanization impacts at an eco-regional scale. Appl. Geogr. 2012, 34, 295-305. [CrossRef]

24. Padmanaban, R.; Bhowmik, A.K.; Cabral, P. Satellite image fusion to detect changing surface permeability and emerging urban heat islands in a fast-growing city. PLoS ONE 2019, 14, e0208949. [CrossRef]

25. Verburg, P.H.; Kok, K.; Pontius, R.G.; Veldkamp, A. Modeling Land-Use and Land-Cover Change; Springer: Berlin/Heidelberg, Germany, 2006; pp. 117-135.

26. Douglas, I. Ecosystems and human well-being. In Encyclopedia of the Anthropocene; Oxford University, Press: New York, NY, USA, 2017; Volumes 1-5, pp. 185-197.

27. Wu, Y.; Ke, Y. Landslide susceptibility zonation using GIS and evidential belief function model. Arab. J. Geosci. 2016, 9, 1-12. [CrossRef]

28. Mo, H.W.; Quan, B.; Yuan, K.G.; Xie, J.N.; Xiang, Y.B. The temporal-spatial dynamic of land ecosystem services value in Guanzhong, Shaanxi. Agric. Res. Arid Areas 2017, 35, 167-172.

29. Yang, X.; Wang, F.; Meng, L.; Zhang, W.; Fan, L.; Geissen, V.; Ritsema, C.J. Farmer and retailer knowledge and awareness of the risks from pesticide use: A case study in the Wei River catchment, China. Sci. Total Environ. 2014, 497-498, 172-179. [CrossRef] [PubMed]

30. Hao, C.F.; He, L.M.; Niu, C.W.; Jia, Y.W. A review of environmental flow assessment: Methodologies and application in the Qianhe River. In IOP Conference Series: Earth and Environmental Science; IOP Publishing: Bristol, UK, 2016; Volume 39, p. 012067.

31. Markham, B.L.; Storey, J.C.; Williams, D.L.; Irons, J.R. Landsat sensor performance: History and current status. IEEE Trans. Geosci. Remote Sens. 2004, 42, 2691-2694. [CrossRef]

32. Hyndman, R.J.; Khandakar, Y. Automatic time series forecasting: The forecast package for R. J. Stat. Softw. $2007,6,07$.

33. Barsi, J.A.; Markham, B.L.; Helder, D.L.; Chander, G. Radiometric calibration status of Landsat-7 and Landsat-5. In Sensors, Systems, and Next-Generation Satellites XI, International Society for Optics and Photonics; International Society for Optics and Photonics: Bellingham, WA, USA, 2007; Volume 6744, p. 67441F.

34. Huanfeng, S.; Xinghua, L.; Qing, C.; Chao, Z.; Gang, Y.; Huifang, L.; Liangpei, Z. Missing Information Reconstruction of Remote Sensing Data: A Technical Review. IEEE Geosci. Remote Sens. Mag. 2015, 3, 61-85.

35. Gao, J. A hybrid method toward accurate mapping of mangroves in a marginal habitat from SPOT multispectral data. Int. J. Remote Sens. 1998, 19, 1887-1899. [CrossRef]

36. Padmanaban, R.; Bhowmik, A.K.; Cabral, P. A remote sensing approach to environmental monitoring in a reclaimed mine area. ISPRS Int. J. Geo-Inf. 2017, 6, 401. [CrossRef]

37. Brunn, A.; Fischer, C.; Dittmann, C.; Richter, R. Quality Assessment, Atmospheric and Geometric Correction of airborne hyperspectral HyMap Data. Geotech. Eng. 2003, 13-16.

38. Andrefouet, S.; Bindschadler, R.; Brown de Colstoun, E. Preliminary Assessment of the Value of Landsat 7 ETM + Data following Scan Line Corrector Malfunction Contributors; US Geological Survey, EROS Data Center: Sioux Falls, SD, USA, 2003.

39. Svetnik, V.; Liaw, A.; Tong, C.; Christopher Culberson, J.; Sheridan, R.P.; Feuston, B.P. Random Forest: A Classification and Regression Tool for Compound Classification and QSAR Modeling. J. Chem. Inf. Comput. Sci. 2003, 43, 1947-1958. [CrossRef] [PubMed]

40. Charrua, A.B.; Padmanaban, R.; Cabral, P.; Bandeira, S.; Romeiras, M.M. Impacts of the Tropical Cyclone Idai in Mozambique: A Multi-Temporal Landsat Satellite Imagery Analysis. Remote Sens. 2021, 13, 201. [CrossRef]

41. Tippmann, S. Programming tools: Adventures with R. Nature 2015, 517, 109. [CrossRef]

42. Klonus, S.; Ehlers, M. Image Fusion Using the Ehlers Spectral Characteristics Preservation Algorithm. GIScience Remote Sens. 2007, 44, 93-116. [CrossRef]

43. Simone, G.; Farina, A.; Morabito, F.C.; Serpico, S.B.; Bruzzone, L. Image fusion techniques for remote sensing applications. Inf. Fusion 2002, 3, 3-15. [CrossRef]

44. Sanli, F.B.; Abdikan, S.; Esetlili, M.T.; Sunar, F. Evaluation of image fusion methods using PALSAR, RADARSAT-1 and SPOT images for land use/land cover classification. J. Indian Soc. Remote Sens. 2017, 45, 591-601. [CrossRef]

45. Feng, R.; Du, Q.; Li, X.; Shen, H. Robust registration for remote sensing images by combining and localizing feature-and area-based methods. ISPRS J. Photogramm. Remote Sens. 2019, 151, 15-26. [CrossRef]

46. Guo, Q.; Ehlers, M.; Wang, Q.; Pohl, C.; Hornberg, S.; Li, A. Ehlers pan-sharpening performance enhancement using HCS transform for n-band data sets. Int. J. Remote Sens. 2017, 38, 4974-5002. [CrossRef]

47. Ye, F.; Xiao, H.; Zhao, X.; Dong, M.; Luo, W.; Min, W. Remote Sensing Image Retrieval Using Convolutional Neural Network Features and Weighted Distance. IEEE Geosci. Remote Sens. Lett. 2018, 15, 1535-1539. [CrossRef]

48. Javan, F.D.; Samadzadegan, F.; Mehravar, S.; Toosi, A.; Khatami, R.; Stein, A. A review of image fusion techniques for pansharpening of high-resolution satellite imagery. ISPRS J. Photogramm. Remote Sens. 2021, 171, 101-117. [CrossRef]

49. Rodriguez, J.J.; Kuncheva, L.I.; Alonso, C.J. Rotation forest: A new classifier ensemble method. IEEE Trans. Pattern Anal. Mach. Intell. 2006, 28, 1619-1630. [CrossRef] [PubMed]

50. Mutanga, O.; Kumar, L. Google earth engine applications. Remote Sens. 2019, 11, 591. [CrossRef] 
51. Silván-Cárdenas, J.L.; Wang, L. Sub-pixel confusion-uncertainty matrix for assessing soft classifications. Remote Sens. Environ. 2008, 112, 1081-1095. [CrossRef]

52. Hayes, M.M.; Miller, S.N.; Murphy, M.A. High-resolution landcover classification using random forest. Remote Sens. Lett. 2014, 5, 112-121. [CrossRef]

53. Rajchandar, P.; Bhowmik, A.K.; Cabral, P.; Zamyatin, A.; Almegdadi, O.; Wang, S. Modelling Urban Sprawl Using Remotely Sensed Data: A Case Study of Chennai City, Tamilnadu. Entropy 2017, 19, 163.

54. O'Neill, R.V.; Riitters, K.H.; Wickham, J.D.; Jones, K.B. Landscape pattern metrics and regional assessment. Ecosyst. Health 1999, 5, 225-233. [CrossRef]

55. Uuemaa, E.; Antrop, M.; Roosaare, J.; Marja, R.; Mander, U. Landscape Metrics and Indices: An Overview of Their Use in Landscape Research. Living Rev. Landsc. Res. 2009, 3, 5-23. [CrossRef]

56. Wu, J.; Shen, W.; Sun, W.; Tueller4, P.T. Empirical patterns of the effects of changing scale on landscape metrics. Landsc. Ecol. 2002, 17, 761-782. [CrossRef]

57. Feng, Y.; Chen, S.; Tong, X.; Lei, Z.; Gao, C.; Wang, J. Modeling changes in China's 2000-2030 carbon stock caused by land use change. J. Clean. Prod. 2020, 252, 119659. [CrossRef]

58. Costanza, R.; D'Arge, R.; De Groot, R.; Farber, S.; Grasso, M.; Hannon, B.; Limburg, K.; Naeem, S.; O’Neill, R.V.; Paruelo, J.; et al. The value of the world's ecosystem services and natural capital. Nature 1997, 387, 253-260. [CrossRef]

59. Zhang, P.; He, L.; Fan, X.; Huo, P.; Liu, Y.; Zhang, T.; Pan, Y.; Yu, Z. Ecosystem Service Value Assessment and Contribution Factor Analysis of Land Use Change in Miyun County, China. Sustainability 2015, 7, 7333-7356. [CrossRef]

60. Sánchez-Canales, M.; Benito, A.L.; Passuello, A.; Terrado, M.; Ziv, G.; Acuña, V.; Schuhmacher, M.; Elorza, F.J. Sensitivity analysis of ecosystem service valuation in a Mediterranean watershed. Sci. Total Environ. 2012, 440, 140-153. [CrossRef]

61. Hasan, S.; Shi, W.; Zhu, X. Impact of land use land cover changes on ecosystem service value-A case study of Guangdong, Hong Kong, and Macao in South China. PLoS ONE 2020, 15, e0231259. [CrossRef]

62. Kreuter, U.P.; Harris, H.G.; Matlock, M.; Lacey, R.E. Change in ecosystem service values in the San Antonio area, Texas. Ecol. Econ. 2001, 39, 333-346. [CrossRef]

63. Su, S.; Li, D.; Hu, Y.; Xiao, R.; Zhang, Y. Spatially non-stationary response of ecosystem service value changes to urbanization in Shanghai, China. Ecol. Indic. 2014, 45, 332-339. [CrossRef]

64. Campos, F.S.; Lourenço-de-Moraes, R.; Ruas, D.S.; Mira-Mendes, C.V.; Franch, M.; Llorente, G.A.; Solé, M.; Cabral, P. Searching for Networks: Ecological Connectivity for Amphibians Under Climate Change. Environ. Manag. 2020, 65, 46-61. [CrossRef]

65. Flasse, S.; Trigg, S.N.; Ceccato, P.; Perryman, A.; Hudak, A.T.; Thompson, M.; Brockett, B.; Drame, M.; Ntabeni, T.; Frost, P.; et al. Chapter VIII Remote sensing of vegetation fires and its contribution to a fire management information system. In Fire Management Handbook for Subsaharan Africa; Goldammer, J., Ronde, C., Eds.; SPB Publishing: The Hague, The Netherlands, 2004 ; pp. 58-211.

66. Liu, Y.; Li, J.; Zhang, H. An ecosystem service valuation of land use change in Taiyuan City, China. Ecol. Modell. 2012, 225, 127-132. [CrossRef] 